\title{
Influence of Steel Fibers on the Account of Permeability Aspects of M20 and M40 Grade Concrete
}

\author{
PL. Meyyappan, M. Jemimah Carmichael
}

\begin{abstract}
Steel Fibre Reinforced Concrete is used in a number of applications such as ground slabs, shotcrete, pavements etc to enhance the performance of plain and reinforced concrete. The study on durability characteristics of fiber reinforced concrete is scanty and hence the study on permeability is essential. This paper deals with the study on the permeability of steel fibre reinforced concrete. Deformed Steel fibres with different volume fraction were used in this study. Permeability was observed to decrease significantly with the addition of fibres and it continued to decrease with the increase in fibre content. Permeability tests were conducted using permeability test apparatus as per IS 3085-1965. Mathematical equations were derived to determine the permeability using the parameters, volume fraction of fibers, and age of curing.
\end{abstract}

Keywords :Steel fibre reinforced concrete; fibre content, Coefficient of permeability; Age of concrete.

\section{INTRODUCTION}

In many researches, identified that, the presence of fibers especially steel fibers significantly improve the various properties of concrete such as compression, tension, flexure and shear. In most practical cases, the well designed concrete structures may hold well in strength criterion aspect but some laggings are seen in the durability aspects. Even though many experimental works have been reported on strength and other aspects on fibre concrete, still there is need to work more on the durability characteristics to improve the performance of concrete in all domains. The permeability study will determine the durability performance of concrete. In the past researches, the effect of various factors like cement type, cement grade, aggregate size, curing methods will impact on the permeability factor. In this study, it is planned to investigate permeability of concrete on different mix ratios along with the various proportions of steel fiber content.

\section{MATERIAL USED}

The materials used in this study were ordinary Portland cement (53 grade), fine, coarse aggregate, and deformed steel fibres. The cement and aggregates were tested to fulfill all the requirements of IS:8112 and IS 383, respectively. Deformed

Revised Manuscript Received on December 05, 2019.

* Correspondence Author

PL. Meyyappan*, Civil department,Kalasalingam Academy of Research and Education, Krishnankoil, India. Email: meyyappan@klu.ac.in

M. Jemimah Carmichael, Civil department, Karunya Institute of Technology and Sciences, Coimbatore, India Email: jemimahcarmicheal@gmail.com steel fibres having an aspect ratio of $60(0.6 \mathrm{~mm}$ in diameter and $36 \mathrm{~mm}$ long) were used in this study.

\section{EXPERIMENTAL INVESTIGATION}

The concrete mix design was arrived using IS method for this experimental study M20 and M40 was 1:1.85:2.5:0.45 and $1: 1: 1.6: 2.3: 0.45$ respectively. Initially the concrete is prepared by the constituents in the dry state. Then the steel fibers were dispersed gradually to achieve uniform distribution in the dry mixture of steel fibre reinforced concrete. Then the water was introduced to prepare the wet mix. Care should be taken while adding water to the dry mix to avoid bleeding and segregation issues. Cylindrical specimens of size $100 \mathrm{~mm}$ (diameter) x $100 \mathrm{~mm}$ (height) is considered for permeability studies for both mixes. Totally 90 cylindrical specimens were cast to permeability test against 7, 14 and 28 days curing and $0 \%, 1 \%, 2 \% 3 \%$ and $4 \%$ fibers content in the volume fraction. As per the standards of IS 3085 , the permeability tests were conducted. The principle behind the test is, to apply the known hydrostatic pressure from one end by allowing the measured amount of water to percolate in the casted cylindrical concrete specimen in the regular time interval and by which the coefficient of permeability can be calculated. The cylindrical concrete specimen is placed on the permeability mould unit of size 110 $\mathrm{mm}$ (diameter) x $110 \mathrm{~mm}$ (height). The test set up comprises of permeability mould unit, graduated capillary glass tube and values for controlling the flow of water. When the test is initiated, the amount of percolated water and the corresponding graduated glass tube readings were observed and recorded at some regular intervals.

The permeability coefficient can be calculated by the formula mentioned below:

$$
K=\frac{Q * L}{A^{*} H}
$$

Where, K -Permeability Coefficient in $\mathrm{m} / \mathrm{sec}$ $\mathrm{Q}$-Discharge rate in $\mathrm{m}^{3} / \mathrm{sec}$

$\mathrm{L}$-Specimen dimension in the direction of flow, $\mathrm{m}$

A -Cross sectional area of the specimen, $\mathrm{m}^{2}$ and

$\mathrm{H}$-Flow able water head, measured in $\mathrm{m}$

\section{RESULT AND DISCUSSION}

The values of coefficient of permeability based on experimental and regression equation for M20 and M40 grade concrete were tabulated in Table 1 against the various volume fraction of steel

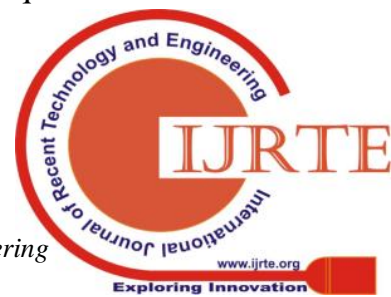


fibers and age of curing days. For without steel fibers, the values of coefficient of permeability are $58.01 \times 10^{-12} \mathrm{~m} / \mathrm{sec}$, $41.44 \times 10^{-12} \mathrm{~m} / \mathrm{sec}$ and $27.62 \times 10^{-12} \mathrm{~m} / \mathrm{sec}$ for the age of 7 days, 14 days and 28 days respectively. This show that concrete become impermeable as the age of curing increased; due to the process of hydration volume of pores were reduced. If the volume of steel fibers increased to $4 \%$, the values of coefficient of permeability decreased drastically to $61 \%$ and $65 \%$ for M20 and M40 grade of concrete respectively. Due to the increased cement content in the M40 grade, there will higher hydration process and thereby reduction of pores is also higher. Figure 1 and 2 shows that the graph plotted between coefficient of permeability and age of curing for M20 and M40 grade of concrete. The impermeability is directly proportional to the age of curing of the concrete even in the presence of steel fibers also.

The coefficient of permeability is reduced radically to $55 \%$ and $62 \%$ for upto $2 \%$ of steel fibers for M20 and M40 grade respectively for the age of curing in 28 days as shown in figure 3 . If the steel fibers are increased to $3 \%$, the coefficient of permeability is marginally increased. If the steel fibers are still extended to $4 \%$, there is a constant level in the impermeable nature on both grades of concrete due to the clustering effect of steel fibers. In this condition, the FRC has no proper workable nature and non homogenous mixing of constituents.

Table- I: Values of Coefficient of Permeability

\begin{tabular}{|c|c|c|c|c|c|}
\hline \multirow{3}{*}{$\begin{array}{c}\text { Volume } \\
\text { fraction } \\
\text { of } \\
\text { fibers }\end{array}$} & \multirow{3}{*}{$\begin{array}{l}\text { Age of } \\
\text { curing } \\
\text { (Days) }\end{array}$} & \multicolumn{4}{|c|}{$\begin{array}{l}\text { Coefficient of permeability } \\
\qquad\left(10^{-12} \mathrm{~m} / \mathrm{sec}\right)\end{array}$} \\
\hline & & \multicolumn{2}{|c|}{$\begin{array}{c}\text { Based on } \\
\text { Experiment }\end{array}$} & $\begin{array}{c}\text { Based on } \\
\text { Eq. } 1\end{array}$ & $\begin{array}{l}\text { Based on } \\
\text { Eq. } 2\end{array}$ \\
\hline & & $M 20$ & $M 40$ & $M 20$ & M40 \\
\hline \multirow{3}{*}{$0 \%$} & 7 & 58.01 & 38.87 & 40.41 & 27.80 \\
\hline & 14 & 41.44 & 29.03 & 27.98 & 19.52 \\
\hline & 28 & 27.62 & 20.06 & 19.38 & 13.71 \\
\hline \multirow{3}{*}{$1 \%$} & 7 & 41.67 & 32.54 & 38.45 & 26.41 \\
\hline & 14 & 30.34 & 23.87 & 26.02 & 18.13 \\
\hline & 28 & 21.08 & 17.12 & 17.42 & 12.32 \\
\hline \multirow{3}{*}{$2 \%$} & 7 & 25.04 & 20.58 & 36.49 & 25.02 \\
\hline & 14 & 17.22 & 13.28 & 24.06 & 16.74 \\
\hline & 28 & 12.53 & 8.86 & 15.46 & 10.93 \\
\hline \multirow{3}{*}{$3 \%$} & 7 & 21.28 & 16.83 & 34.53 & 23.63 \\
\hline & 14 & 14.64 & 10.78 & 22.10 & 15.35 \\
\hline & 28 & 10.65 & 7.8 & 13.50 & 9.54 \\
\hline \multirow{3}{*}{$4 \%$} & 7 & 20.22 & 15.65 & 32.57 & 22.24 \\
\hline & 14 & 13.91 & 9.83 & 20.14 & 13.96 \\
\hline & 28 & 10.12 & 6.97 & 11.54 & 8.15 \\
\hline
\end{tabular}

In order to verify the experimental data by statistically, regression analysis was carried out to determine the best-fit relationship between coefficient of permeability, curing days and percentage volume fraction of fibers for the mix M20 and M40 grade of concrete.
The best-fit equation 1 and 2 is obtained for M20 and M40 grade concrete and it is given below:

$$
\begin{aligned}
& K=113.33 D^{-0.53}+2.223 S_{f}^{2}-15.96 S_{f}+42.97 \\
& K=82.30 D^{-0.51}+1.105 S_{f}^{2}-9.393 S_{f}+30.29
\end{aligned}
$$

Where, K-Coefficient of permeability in $\mathrm{m} / \mathrm{sec}$

$\mathrm{D}$ - Age of curing in days

$\mathrm{S}_{\mathrm{f}}-$ Volume fraction of steel fibers in percentage

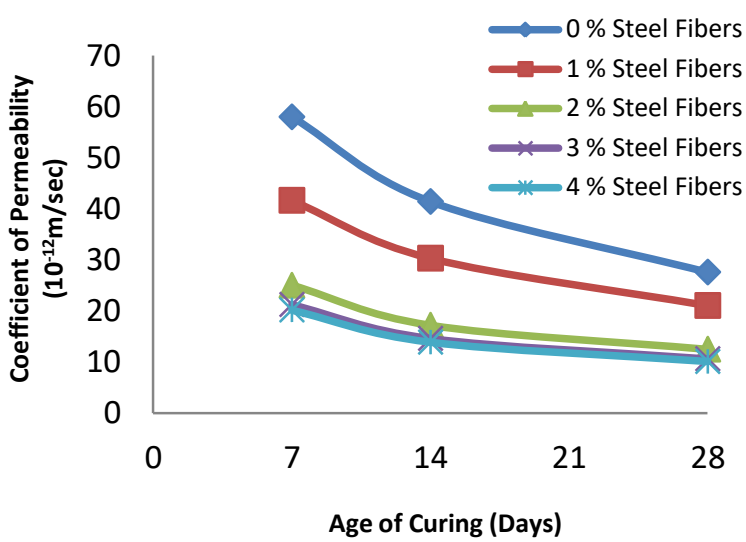

Fig. 1.Coefficicent of Permeability Vs Age of curing for M20 concrete

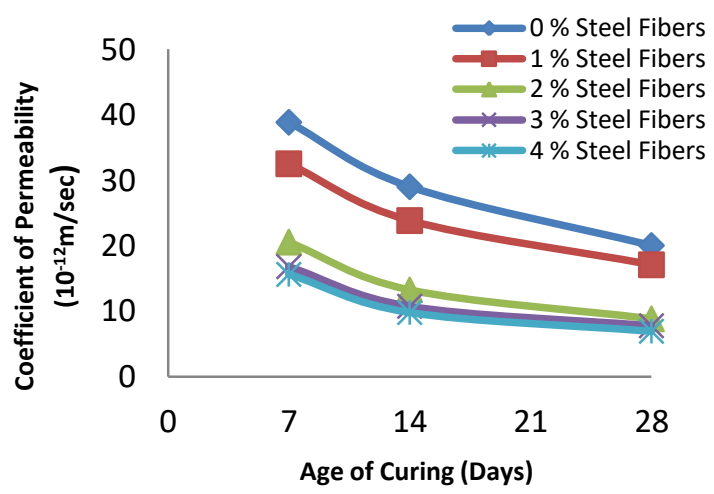

Fig. 2. Coefficicent of Permeability Vs Age of curing for M40 concrete

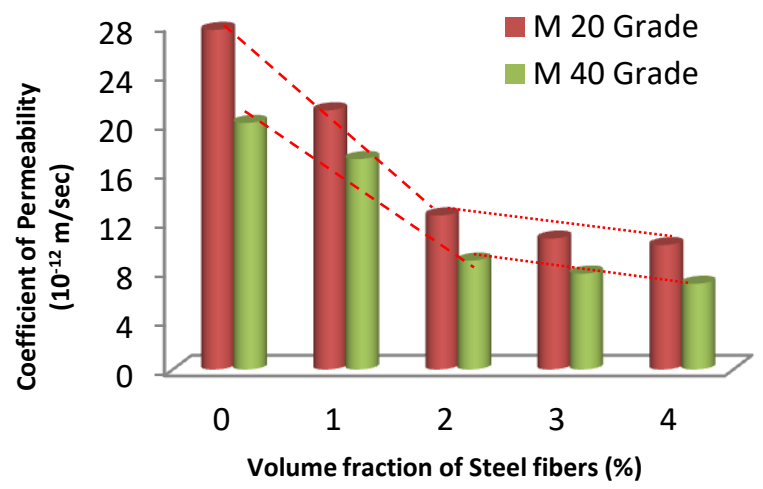

Fig. 3. Coefficicent of Permeability Vs Steel fibers (M20 \& M40)

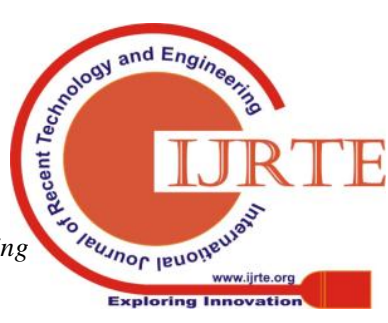


The comparison of coefficient of permeability values based on experimental results and regression equation with volume fraction of steel fibers is tabulated table 1 and the graph is plotted on figure 4 and 5 respectively for M20 and M40 grade concrete. It is clearly understood that the experimental values of coefficient of permeability and regression values are correlated in the range of plus or minus 25.

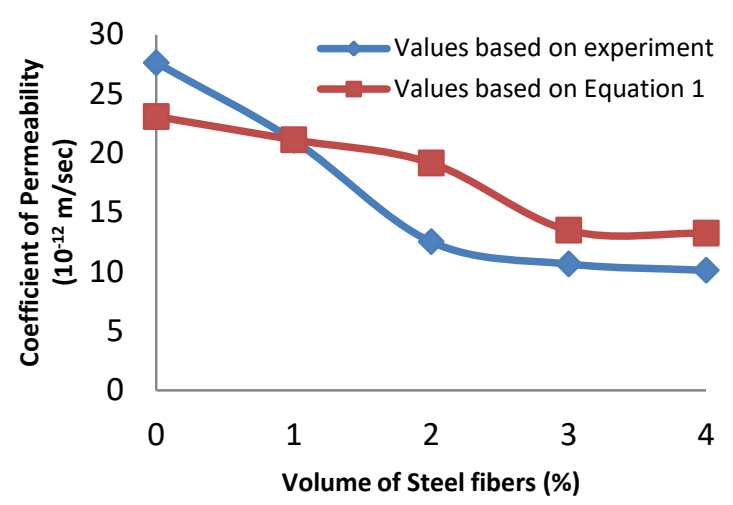

Fig. 4.Comparision of experiemental and equation values (M20)

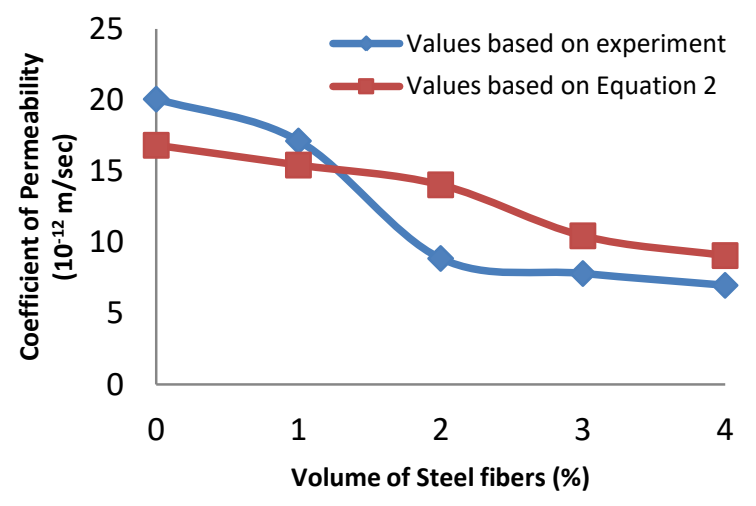

Fig. 5.Comparision of experimental and equation values (M40)

\section{CONCLUSIONS}

1) Addition of steel fibers into concrete resulted in significant decrease in permeability due to arrest of plastic shrinkage cracks.

2) The decrease in permeability with the addition of steel fibers continued with increase in volume of fraction of fibers.

3) Permeability of steel fiber reinforced concrete decrease with increase in fiber content.

4) The Permeability of steel fiber reinforced concrete as well as plain cement concrete decreased with increase in cement content.

5) Theoretical equations have been developed for permeability in terms of, age of concrete and volume fraction of steel fibers and the theoretical values were found to correlate in good agreement with the experimental values.

\section{REFERENCES}

[1] EI-Dieb A.S and Hooton R.D. (1995) "Water-permeabilitymeasurement of high performance concrete using a high-pressure triaxial cell". Journal of Cement and ConcreteResearch, Vol.25, No.6, pp.1199-1208.

[2] O. Deo, M. Sumanasooriya, and N. Neithalath, "Permeability reduction in pervious concretes due to clogging: experiments and modeling," Journal of Materials in Civil Engineering, vol. 22, no. 7, pp. 741-751, 2010.

[3] M. Sonebi and M. T. Bassuoni, "Investigating the effect of mixture design parameters on pervious concrete by statistical modelling," Construction and Building Materials, vol. 38, pp. 147-154, 2013.

[4] IS 516-1959 (1959). "Methods of tests for strength of concrete".Bureau of Indian Standards.

[5] IS 3085-1965 (1965). "Method of test for permeability ofcement mortar and concrete". Bureau of Indian Standards.

[6] Khan M.I. and Lynsdale C.J. (2002). "Strength, permeability,and carbonation of high-performance concrete". Journal ofCement and Concrete Research, 32 (2002), 123131.

[7] Miloud B. (2005). "Permeability and porosity characteristics ofsteel fiber reinforced concrete." ASIAN JOURNAL OF CIVILENGINEERING (BUILDING AND HOUSING), Vol. 6, No.4, pp.317-330

[8] PL. Meyyappan, K.Kumaran, M.Gopalakrishnan and E. Harikrishnan (2018), "Effect of glass fibers, flyash and quarry ash on Strength and Durability Aspects of Concrete - An Experimental Study", IOP Conference Series: Material Science and Engineering, doi:10.1088/1757-899X/396/1/012001.

[9] PL. Meyyappan, K.Kumaran, M.Gopalakrishnan and E. Harikrishnan (2018), "Experimental Investigation on the Effect of Silica fume and Pumice stone in Developing Light Weight Concrete", IOP Conference Series: Material Science and Engineering, doi:10.1088/1757-899X/561/1/012064

[10] PL. Meyyappan, P. Amuthakannan, R. Sutharsan and M. Ahamed Azik Ali (2019), "Utilization of M-Sand \& Basalt Fiber in Concrete: An Experimental Study on Strength and Durability Properties", IOP Conference Series: Material Science and Engineering, doi:10.1088/1757-899X/561/1/012035.

\section{AUTHORS PROFILE}

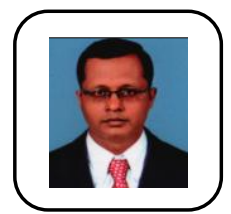

Dr. PL. Meyyappanhas completed his graduation and post-graduation from Bharathiyar University and Karunya University respectively. He completed his $\mathrm{PhD}$ from Kalasalingam University. He has 13 years of teaching experience. He has completed 2 sponsored research projects from TNSCST and published more than 25 papers in peer reviewed journals and conferences. He is a life member in ISTE, IEI, IGS, ISET, ISRS. He is serving as Editorial Board Member and Reviewer in various reputed Journals.

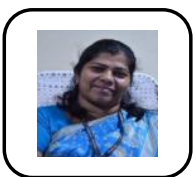

M. Jemimah Carmichael hascompleted her graduation and post-graduation from Bharathidhasan University and Bharathiyar University respectively. Shehas submitted her PhD thesis in Karunya University. She has 22 years of teaching experience. She has published more than 15 papers in peer reviewed journals and conferences. 